\title{
Entre Florestas, Loucuras e Profecias: os Merlins medievais, suas adaptações e ressignificações
}

\author{
Between Forests, Madness, and Prophecies: \\ the medieval Merlins, adaptations and reframings
}

\begin{abstract}
Lunielle de Brito Santos Bueno ${ }^{1}$
${ }^{1}$ Graduada em História pela Universidade Estadual de Londrina, Londrina-PR. Mestranda em História Social pela Universidade Estadual de Londrina - UEL, Londrina-PR. Bolsista CAPES. Orientadora: Monica Selvatici. E-mail: luniellebueno@gmail.com.
\end{abstract}

Recebido em 5 de outubro de 2020; Aceito em 24 de abril de 2021

DOI: $10.12957 /$ nearco.2021.55076

\section{Resumo}

Neste artigo buscamos analisar os usos do personagem Merlin nas obras de Godofredo de Monmouth, do século XII e de Roberto de Boron, do século XIII, bem como as adaptações e ressignificações de uma obra para outra, a partir dos contextos sociais e políticos. Nesses, ambos os autores usaram do personagem para criticarem ou para exaltarem a situação política do local, no passado ou no presente da produção de suas obras. Salientamos que a figura de Merlin, narrativamente e visualmente, tornou-se um modelo para os magos modernos e contemporâneos das literaturas e produções audiovisuais. Todavia, enquanto as características do personagem se assemelham as do Merlin gestado no medievo, as imagéticas são pautadas pelo medievalismo, ou seja, características que não necessariamente estava presente nas produções imagéticas e literárias do período medieval.

Palavras-chave: Merlin; Literatura; Medievalidade; Ressignificação.

\begin{abstract}
In this paper we seek to analyze the uses of the Merlin character in the works of Geoffrey of Monmouth, from the 12th century, and of Robert of Boron, from the 13th century, as well as the adaptations and resignifications from one work to another, based on the social and political contexts. In these, both authors used the character to criticize or to exalt the political situation of the place, in the past or in the present, of the production of their works. We point out that the figure of Merlin, narratively and visually, has become a model for modern and contemporary wizards in literatures and audiovisual productions. However, while the character traits resembled those of the medieval Merlin, the Merlin's images were established by medievalism, that is, they were not necessarily present in the imagery and literary productions of the medieval period.
\end{abstract}

Keywords: Merlin; Literature; Medievality; Resignification. 
Fazemos parte de uma geração influenciada pela fantasia que a literatura, os jogos e o cinema trouxeram com suas superproduções. Mundos fantásticos e maravilhosos, bem como personagens inusitadas, são cada vez mais recorrentes entre as preferências do público, e elementos de um passado medieval estão entre os mais buscados por essas produções midiáticas.

Suntuosos castelos, poderosos reis e rainhas, grandes batalhas com guerreiros e seres mágicos são os arquétipos medievais que sobrevivem no imaginário contemporâneo, sendo fortemente reforçado por produções da cultura de massas. 0 resgate desses elementos medievais passa são adaptados e ressignificados para o tempo presente. Tais processos, que também podem ser caracterizados como medievalismo, apresentam cenários, temas e personagens que muitas das vezes estão colocados nos registros e documentos da Idade Média e, apesar da distância temporal, alguns elementos permanecem similares, outros, por sua vez, parecem sofrer influências de outros tempos históricos. Um dos personagens, o qual está presente nas produções de ficção na contemporaneidade e foi gestado no medievo, é o Merlin.

Por um lado, temos o chapéu pontiagudo e alto, túnicas, barba longa, velho e com um cajado como algumas das características que associamos ao Merlin, imageticamente falando. Por outro, um ser mágico que ajuda Artur e que também dialoga com animais são características que aparecem nos enredos em que o personagem aparece. Todavia, essas características nem sempre remontam à Idade Média. Dito isto, a proposta deste trabalho é fazer uma comparação entre as literaturas medievais dos séculos XII e XIII, na obra de Godofredo de Monmouth, Vita Merlini, e de Merlin, de Roberto de Boron, a fim de que possamos compreender quais elementos estão presentes nesses primeiros séculos em que o personagem Merlin aparece na literatura medieval e quais elementos, possivelmente, são de outros tempos históricos.

Assim, a obra Vita Merlini, do erudito galês Godofredo de Monmouth, foi escrita no século XII, em 1148 aproximadamente, na Inglaterra, em forma de poemas hexâmetros. Composta, originalmente em latim, Vita Merlini se difere das demais obras do autor que também têm Merlin como personagem - Prophetiae Merlini e Historia Regum Britanniae -, por apresentar o personagem como rei em vez dos modelos 
posteriormente preponderantes de mago e profeta. $\mathrm{O}$ escrito se encontra bastante fragmentado e, provavelmente, as bases desse, segundo Jean Markale, poderiam ser a continuação de Prophetiae Merlini, pautada em tradições orais sobre Nennius, um bardo profeta que teria vivido no século $V(1989$, p. 13).

Por outro lado, Merlin, de Roberto de Boron, foi escrito no início do século XIII, em francês. Originalmente em octossílabos, a obra sobrevive em prosa constituída a partir dos fragmentos encontrados. É válido ressaltar que Roberto de Boron foi o primeiro a denotar ao mito do Santo Graal um sentido cristão.

A ideia de compreender que características são ou não da Idade Média nessas duas obras pauta-se no fato de que Merlin se tornou o modelo de mago a se seguir. Os primeiros Merlins das literaturas e, posteriormente, os das pinturas, dos teatros e dos filmes abarcaram uma série de características psicológicas (ou de personalidade) e visuais que fomentaram a idealização de outros personagens mágicos desde então. Dumbledore, Gandalf e magos dos jogos de RPG são exemplos das influências que esse personagem teve, e continua a ter, para as criações do século XX e XXI.

Todavia, os usos desses magos em narrativas nem sempre são as mesmas. $\mathrm{Na}$ literatura medieval, por exemplo, os conflitos políticos da Inglaterra e França estão impressos em ambos os poemas. Por conseguinte, o posicionamento dos autores, colocados na construção dos Merlins, são elementos que devem ser considerados. Assim, uma pergunta secundária a partir de nossos estudos se formam, a saber, que papeis esses magos/conselheiros desempenham na narrativa?

Uma resposta prévia a essa pergunta pode ser a de que, na Europa Ocidental dos séculos XII e XIII, a figura de Merlin, bem como o enredo arturiano, foi utilizada no medievo para fins políticos dos grupos detentores do poderio. As obras que contêm como personagem Merlin geralmente visavam o fortalecimento do reino através dele (ZIERER, 2013, p. 155).

Uma das bases dessa resposta é pautada na ideia de que Merlin, conselheiro e guia do rei Artur, auxilia os bretões a vencerem os saxões em doze batalhas, sendo a principal a Batalha de Monte Badon. E, apesar de não sabermos se as batalhas existiram ou não, no século VI, os saxões conseguiram dominar a Bretanha. Sete reinos foram 
implementados, todos independentes, e ficaram conhecidos como a heptarquia anglosaxônica (ZIERER, 2013, p. 155). Entretanto, em 1066, Guilherme I da Normandia, conquistou a região na Batalha de Hastings e, a partir de então, toda a região da GrãBretanha acabou controlada pela Dinastia Normanda, formada por senhores feudais de domínios franceses e reis ingleses.

Descendentes dos celtas, os bretões viviam em tribos rivais, cada uma sendo governada por um rei ou chefe, importante somente nos momentos de guerra (ZIERER, 2013, p. 155). Em consequência dessa fragmentação, os bretões foram conquistados por diferentes povos, como no século I, pelos romanos e no século VI, pelos saxões. E nesse primeiro período, no qual foram incorporados ao Império Romano, os druidas sofreram bastante perseguição.

Do druidismo pouco se sabe com certeza, mas estudos apontam que os druidas, nos registros escritos de diversos pensadores como Amiano Marcelino, Júlio César e Plínio, executavam atividades que variavam: juízes, médicos, mentores da filosofia ética, conselheiro de reis, poetas, sábios que utilizavam do artifício de adivinhar para ensinar, adivinhos, $^{227}$ intelectuais, participantes de guerras e executores de funções religiosas. Resumidamente, "os druidas eram intelectuais [...] tinham especial sabedoria acerca da natureza em geral tanto da astronomia e cosmologia como dos reinos animal e vegetal; e exerciam funções jurídicas, e políticas além das pedagógicas" (LUPI, 2004, p.71-72).

Dito isto, antes da Bretanha ser parte do Império Romano, os druidas possuíam excelente reputação, mas, com a conquista, perderam o prestígio aos poucos, e essa situação pode ser explicada a partir de duas premissas. A primeira delas é de que sob o olhar romano, os druidas se converteram gradualmente em uma classe religiosa dedicada a superstições e feitiçarias. A segunda é que os escritores romanos eram favoráveis à política de ocupação, e suas críticas aos druidas serviam para reforçar a conquista.

Porém, como numa relação dialética das duas explicações apresentadas, acreditamos que a síntese do que pode ter levado à perseguição é a explicação mais

\footnotetext{
${ }^{227}$ Vale lembrar que, apesar de algumas associações vincularem os druidas com os adivinhos, ambos, dentro da tradição céltica, pertenciam a grupos diferenciados (BIRKHAN, 2003, p.100).
} 
completa. Assim, o fato se justifica pela resistência representada pelos druidas frente à dominação romana. Por fim, com o declínio de Roma e os constantes ataques de escotos, pictos e saxões, os romanos perderam a ilha para os saxões, associados aos anglos e aos jutos.

\section{Merlin na narrativa de Godofredo de Monmouth}

Após a invasão saxã, alguns bretões fugiram para a região da Armórica e outros resistiram na região do atual País de Gales. Nesta região nasceu uma das principais obras de Merlin, Vita Merlini, de Godofredo de Monmouth.

No período de composição da obra, o contexto político vivido pelo autor na Inglaterra era conturbado, e em sua escrita é retratada a problemática sucessão do trono após a morte do rei Henrique I, da dinastia Normanda. A própria dinastia (que começa em 1066 com Guilherme I, O Conquistador) era vista como estrangeira pelos ingleses, pois a Normandia fica ao noroeste da França. Todavia, apesar dos problemas externos relacionados à aceitação da Dinastia, problemas internos como a morte do herdeiro por um naufrágio, no ano de 1120, e a existência de um filho ilegítimo, Roberto de Gloucester, também pesavam sob a cabeça de Henrique I. Disto, segue-se que o trono foi reconhecido pelo rei como de direito de Matilda I, sua filha, casada com o conde de Anjou.

Os nobres ingleses, bastante marcados por uma tradição saxã extremamente nacionalista, receosos com o histórico de estrangeiros no poder da Inglaterra, ao verem o marido de Matilda I, Godofredo V de Anjou ou Godofredo Plantageneta, no poder junto à filha de Henrique I, encararam o fato como inconcebível. Então, após o falecimento de Henrique I, Estevão de Blois assumiu o trono inglês, contrariando a vontade de seu tio, o antecessor, e travando uma disputa sociopolítica com a prima e seu marido.

Enquanto Estevão tinha o apoio de nobres e da Igreja Católica, Matilda I conseguiu o apoio de seu meio irmão, Roberto, e de seu tio David I, da Escócia. Após angariar forças políticas e militares para conseguir o trono, Matilda invadiu a Inglaterra e, na Batalha de Lincoln, em 1141, capturou seu primo. 
Entretanto, mesmo com a captura do então rei por usurpação, Matilda não conseguiu ser coroada. Os motivos eram o descontentamento popular em relação a figura dela, bem como o sequestro de seu meio irmão, Roberto. Desistindo de suas convicções políticas e cercada pelos guardas de Estevão, Matilda assinou um acordo de troca entre os prisioneiros (Estevão e Roberto) e voltou para Normandia, junto de seu marido. Entretanto, seu filho, Henrique II, continuou na Inglaterra a fim de conquistar o trono inglês e, após excessivos acordos, conseguiu alçar o cargo de rei, em 1154.

Inserido nesse contexto, Godofredo nasceu aproximadamente no ano 1100, em Monmouth, território do atual País de Gales. Em seus escritos, como no próprio Vita Merlini, ele referia-se a si mesmo como "Godofredo de Monmouth", tendo ficado conhecido desta forma. Em 1152, Godofredo foi consagrado bispo de Santo Asafe pelo arcebispo Teobaldo, em Lambeth, e, no ano de 1155, faleceu.

Indícios mostram que ele pode ter se dedicado ao convento beneditino por um curto período e, ainda em vida, ter se vinculado à Universidade de Oxford como cânone secular na faculdade de St. Georges. Além disso, era patrocinado pelo bispo de Lincoln, Alexandre, até a morte deste em 1148 , e, posteriormente, pelo sucessor, Roberto de Chesney, a quem dedicou o poema Vita Merlini.

A obra foi escrita entre os anos 1148 e 1151, em forma de poemas hexâmetros. Originalmente em latim, diferindo das obras anteriores do autor, Vita Merlini é apresentada como a origem do profeta que posteriormente ajudaria aos grandes reis da Inglaterra. A fim de aprofundarmos nossa análise acerca da obra em questão, buscamos apresentar e compreender os escritos anteriores do autor, Prophetiae Merlini e Historia Regum Brittaniae.

Prophetiae Merlini foi escrita por volta de 1134. Nela podemos constatar a primeira aparição de Merlin na literatura. Foi dedicada a Alexandre, bispo de Lincoln, seu patrocinador. Nesta obra, a figura de Merlin é apresentada como "Merlin Ambrosius", inspirado na figura do rei Aurélio Ambrósio. Jean Merkale aponta que Godofredo reestruturou um mito corrente da época, consolidado por Nennius, em Historia Brittonum. Por sua vez, Nennius foi um monge que, após sua morte, passou a 
ser retratado de mateira mitologizada, como um bardo profeta e protetor do povo bretão (MERKALE, 1989, p.59).

Assim, Godofredo, ao escrever Prophetiae Merlini, apropriou-se de elementos da obra de Nennius, dentre os quais podemos destacar a narrativa de Vortigern, as duas serpentes (uma branca e uma vermelha) que foram substituídas por dragões, a profecia de derrota da Bretanha diante dos Saxões e o vínculo de Stonehenge com a tradição céltica (PEREIRA; MATIAS, 2013, p.64). Outra similaridade é a origem de Merlin. Por ser filho de um íncubo com uma donzela, é capaz de fazer previsões que, na tradição céltica, seria o equivalente a um euhagis, classe responsável por fazer provisões (SILVA, 2002, p.63).

Sua outra obra, Historia Regum Brittaniae, foi escrita durante os anos de 1135 e 1138 e dedicada a Roberto, filho do rei Henrique I, que encomendou a obra (ZIERER, 2002, p.49). Este livro retomou a origem demoníaca do mago e profeta, repetindo a versão inspirada por Nennius. Merlin é conselheiro de Uter Pendragão, e, graças a uma poção mágica que faz Uter se parecer com o marido de Igerna, Duquesa de Tintagel, Gorlois - que estava morto em batalha -, Merlin propicia o nascimento de Artur. Nesta obra, contudo, a interação das figuras de Merlin e Artur se restringe ao nascimento do rei, tema que será transformado e mais bem explicado em Roberto de Boron, como veremos posteriormente.

Já em Vita Merlini, Godofredo de Monmouth explora uma nova face de Merlin. O personagem se aproxima de Myrddin que pode ter vivido, aproximadamente, no século VI no Sul da atual Escócia. Merlin, na obra em questão, é um sábio rei que, após uma batalha devastadora em que três dos seus irmãos morrem, perde o juízo e o encantamento com o mundo. Por isso, Merlin refugia-se na floresta de Caledônia, também no Sul da Escócia e, por isso, é conhecido como Merlin Celidônio (PEREIRA; MATIAS, 2013, p.65).

A ligação deste Merlin com Myrddin é visível pelos nomes dos personagens que são similares aos da lenda do bardo: Merlinus - Myrddin, Thelgesinus Taliesin/Talgesin, Guendolena - Chwimlean e Rodarchus Largus - Rhyedderch Hael. Também podemos ver semelhanças pelas queixas cantadas nos bosques por ambos os 
personagens, bem como a característica selvática e profética. Além disso, notamos que o poeta, nesta última obra, não associa a figura de Merlin ao mundo de Uter e Artur, como anteriormente, sobretudo por se tratar da possível 'origem' de Merlin, que antecederia sua ligação com os reis Uter e Artur (GUAL, 1994, p. xxiv).

Assim, Vita Merlini insere Merlin numa temática não vista antes. O personagem é apresentado como rei que, após enfrentar uma batalha que causou a morte de seus irmãos, passa a viver como um animal em um exílio na floresta. Nesta, Merlin vê o lugar como seu lar e os animais que lá vivem, como seus companheiros. Por permanecer muitos anos isolado, toda vez que é levado para o reino de sua irmã, Ganieda, age de maneira irrequieta, agindo de forma violenta e exagerada a fim de retornar ao convívio com a natureza.

Quando se exila na floresta, Merlin demonstra se sentir bem, mesmo enxergando nesse ato uma forma de autopunição, por se sentir responsável pela morte de seus irmãos. Tal postura é vista como loucura por aqueles que tem contato com o personagem. Entretanto, ela é apresentada pelo autor como a mais esplêndida graça divina, isso pois Merlin ganha status de separado por Deus no decorrer da narrativa (PEREIRA; MATIAS, 2013, p.78-79).

Além disso, pensando nos aspectos gerais,

Vita Merlini é um texto heterogêneo com uma forma irregular. Por um lado, em seus versos nota-se a mão de um clérigo que extrai de suas leituras escolares uma erudição um tanto enciclopédica, um tanto curiosa. Por outro lado, o autor desenha a silhueta do protagonista Merlin [...] O sábio Merlin é antes de tudo um estranho solitário, enlouquecido pelo espetáculo da batalha sangrenta e fratricida, que quer se retirar para a solidão desumana e sombria das florestas, viver ali na companhia de animais selvagens (GUAL, 1994, p. xxvi). ${ }^{228}$

\footnotetext{
${ }^{228}$ La Vita Merlini es un texto abigarrado y de factura irregular. Por un lado em sus versos se nota la mano de um clérigo que extrae de sus lecturas escolares una erudición un tanto enciclopédica, un tanto curiosa. Por outro lado, el autor dibuja una silueta del protagonista, Merlín [...] El sabio Merlín es ante todo un extraño solitario, enloquecido ante el espectáculo de la sangrienta y fratricida batalla, que quiere retirarse a la inhumana y tenebrosa soledad de los bosques, para habitar allá em compañía de los animales salvajes.
} 
Como podemos perceber, no trecho acima, Gual aponta o vasto conhecimento de Godofredo na obra, como o conhecimento de animais diversos e de regiões geográficas das ilhas britânicas dominadas por saxões e bretões. Todavia, para além do conhecimento geográfico, na visão de Merlin enlouquecido, Godofredo critica a sociedade e seu contexto histórico. Ao dar continuidade em apresentar a obra, Gual escreveu que o Merlin em Vita Merlini é caracterizado como "enlouquecido perante o espetáculo da batalha sangrenta e fratricida". Neste trecho, Godofredo, ao fazer uma comparação da batalha que deixou Merlin louco com a guerra civil vivida por ele na Inglaterra, critica a guerra entre povos de um mesmo país. As consequências desses embates na vida de todos, inclusive, a do próprio rei é a condição de possibilidade de ficar como o Merlin diante dessa situação: estranho, solitário e enlouquecido.

Gual, ao colocar que Merlin preferia se retirar para a "solidão inumana e sombria dos bosques" e habitar junto aos animais, aponta para mais uma possível crítica do autor em relação à sua sociedade, a saber, viver entre animais é mais saudável e benéfico que viver numa sociedade desumana e sangrenta. Ademais, ao colocar na visão de um Merlin enlouquecido as profecias advindas dos céus, Godofredo concebe a visão mais profunda ao louco, e através dessa, a crítica ao seu contexto histórico vem em forma de profecia

[...] furiosa loucura dos bretões, que a excessiva abundância perturba e exalta além do que é devido! Eles não querem gozar da paz, eles se agitam com as ferroadas da fúria infernal, eles movem a guerra civil, combates fratricidas, eles toleram a ruína das igrejas do Senhor, eles expulsam os santos pontífices para o exílio em reinos distantes, os descendentes do javali de Cornualha. Ao fazer ameaças a si mesmos, eles se matam como espadas execráveis. Não querendo esperar para tomar a coroa por direito legítimo, eles a arrebatam (MONMOUTH, 1994, p.22). ${ }^{229}$

\footnotetext{
${ }^{229}$ [...] locura furiosa de los britanos, a los que la excesiva abundancia trastorna y exalta más allá de lo debido! No quieren gozar de la paz, se acicatean com aguijones de furia infernal, mueven guerra civil, combates fratricidas, toleran la ruina de las iglesias del Señor, espulsan a destierro em lejanos reinos a los sagrados pontífices, todo lo conturban los descendientes del jabalí de Cornubia. Poniéndose acechanzas a sí mesmos, a sí mesmos dan muerte com execrable espadas. No queriendo aguardar a tomar la corona por legítimo derecho, la arrebatan.
} 
Nesse pequeno excerto, retirado do diálogo entre Merlin e sua irmã Ganieda, percebemos certos marcos históricos apresentados na obra. Esses marcos se vinculam intrinsecamente a acontecimentos históricos contemporâneos à vida do autor. Quando escreveu "movem guerra civil, combates fatricidas", refere-se à própria guerra civil ocasionada pela disputa de sucessão do trono inglês entre a herdeira legítima de Henrique I e seu sobrinho, Estevão. Ao destacarmos a passagem "expulsam os santos pontífices para o exílio em reinos distantes", podemos vincular ao primeiro exílio de Teobaldo de Bec, arcebispo da Igreja da Cantuária, responsável pela consagração de Godofredo de Monmouth como bispo. Isso aconteceu devido ao fato de Teobaldo ter participado do Concílio de Reims, sendo o primeiro contrário às ordens do então rei Estevão, no começo do ano 1148. Teobaldo foi exilado pelo rei na região de Saint-Omer, atual França (DAVIS, 1990, p.52-53).

E, por fim, ao escrever "Não querendo esperar para tomar a coroa por direito legítimo, eles a arrebatam", remete-se ao episódio da tomada do trono pelo primo Estevão da então sucessora por direito Matilda I. Por conta desse episódio, Matilda I ficou impossibilitada de exercer o cargo de rainha da Inglaterra. Como consequência, houve uma guerra civil e a crítica e Godofredo se estende aos apoiadores de Estevão por, a saber, os nobres ingleses que não queriam outro estrangeiro no poder, como Godofredo Plantageneta, da França.

Além disso, apesar de Merlin nesta obra parecer com um "eremita cristão", os elementos pagãos, que são predominantes nos versos, não são sistematizados em Vita Merlini. Os elementos pagãos mais visíveis encontram-se nas passagens em que o autor se remete ao Zodíaco para que Merlin tenha suas previsões políticas e na passagem do encantamento das maçãs. A partir desses elementos dados por Godofredo, podemos fazer uma ligação aos conflitos anteriores, na Gália, entre os bretões partidários do Império Romano (bretões do Sul) e os partidários da Independência (bretões do Norte), prontos a se aliarem aos saxões e aos pictos, a fim de eliminar qualquer influência romana.

Vale ressaltar que, após a queda do Império Romano, os bretões do Norte foram responsáveis pelo retorno dos elementos celtas, bem como tiveram um papel de 
destaque nas lutas contra os invasores saxões, anglos e pictos, por exemplo (MARKALE, 1989, p.17-18). Nesses trechos também podemos perceber a forte influência da narrativa céltica, Merlin em Vita Merlini, assemelha-se a um druida pelo interesse partilhado entre esses sobre astronomia e natureza (LUPI, 2004, p.73).

\section{Merlin na narrativa de Roberto de Boron}

Uma das características mais marcantes da história da França moderna é o Absolutismo, que pode ser definido, em seu auge, como movimento em que o poder se encontrava centralizado nas mãos do monarca, tendo como características a superação da relação de vassalagem, aproximação com a burguesia e a independência do poder da Igreja.

Ao se configurar como um processo característico da Idade Moderna, o Absolutismo teve seu início no medievo, especificamente na virada dos séculos XII e XIII, com o reinado de Filipe II, de 1180 a 1223, da Dinastia Capetíngia.

Em anos de Cruzadas e de conflitos com a Dinastia Plantageneta na Inglaterra, Filipe II, numa tentativa de se fortificar frente aos conflitos militares, formou um exército nacional profissional, fato que rompe com a dependência da relação de vassalagem. Esse exército ajudou em suas conquistas sobre os domínios ingleses, também foram de suma importância nas decisões dos conflitos com Ricardo I e, posteriormente com seu sucessor, João I; e é nesse contexto de mudança política e conflitos motivados também por questões religiosas que se insere Merlin, de Roberto de Boron.

Vindo de Montbéliard, no atual departamento de Doubs, Roberto era clérigo e está presente em relatos na região da Grã-Bretanha desde o ano 1200. Provavelmente, frequentou a corte dos Plantagenetas, dinastia sucessora da Normanda na Inglaterra, e representou em suas obras uma forte tradição cristã (MARKALE, 1989, p.22).

Os escritos de Roberto de Boron estão situados entre os anos de 1191 e 1212 e acredita-se que tenha composto suas obras para Gautier de Montbéliard. Cavaleiro que partiu em cruzada em 1202, e em 1212, morreu em combate. Conhecido por ser de Boron, uma cidade na região da Borgonha, próximo a Montbéliard, Roberto foi o 
primeiro a inserir o mito do Santo Graal em relação com o mito de Merlin e Artur sob um novo víes (BOGDANOW, 1994, p.179).

A região da Borgonha foi fortemente influenciada pelo monasticismo, sobretudo por Cluny e Cîteaux. Com o desmembramento do Império Carolíngio, essa região se dividiu em duas unidades políticas, a saber, por um lado, depois de 1032, passou para o Império Germânico, formando o Reino da Borgonha. Por outro lado, o Ducado da Borgonha foi mantido pelos francos e dominado pelos membros da Dinastia Capetíngia até 1361.

Merlin, de Roberto de Boron, encontra-se, originalmente, inserido num díptico em versos e contido nele está a história do Graal, chamada de Joseph ou Le Roman de I'Estoire du Graal e Estoire de Merlin. Joseph sobreviveu em sua forma completa, seguido pelos primeiros 504 versos de Merlin, em octassílabos. A obra sobrevive pelos fragmentos encontrados a partir da prática de transformar em prosa os romances arturianos, bem como pela prática de combinar narrativas em ciclos maiores. Tal movimento também engloba os escritos de Roberto (BOGDANOW, 1994, p.179).

Nos manuscritos em prosa, os escritos Joseph e Merlin são seguidos de mais dois livros, a Demanda do Santo Graal e Didot Perceval (nesse último narra-se a morte de Artur). Essas duas obras, que dão sequência às de Roberto, são atribuídas erroneamente ao autor. Entretanto, na maioria dos manuscritos posteriores, a sequência ganha um volume a mais, sendo então: Estoire del Saint Graal (baseado em Joseph em prosa); Merlin seguido de uma continuação conhecida como Suite Merlin da Vulgata; Lancelot em prosa (adaptação da obra Charrete de Chrétien de Troyes); Queste del Saint Graal e o desfecho com a Mort le Roi Artu.

Dito isto, Roberto de Boron escreveu o livro no formato de romance, mesmo que originalmente sua obra esteja em versos. Ao entendermos que o romance, no medievo, se caracterizava por envolver a glosa, ou seja, a língua vulgar, "ao alcance dos ouvintes", o autor, ao escrever em francês e não em latim, ganha o status de romancista (ZUMTHOR, 1993, p.266-267).

Influenciado por dois importantes poetas e romancistas franceses que se inserem como importantes figuras para a circulação e construção do Ciclo Arturiano, 
Chrétien de Troyes e Wace, e provavelmente, por Godofredo de Monmouth, Roberto de Boron integrou Merlin ao universo cavaleiresco. Todavia, uma mudança significativa entre os escritos de Roberto de Boron e os escritos anteriores deve ser mencionado. 0 personagem Merlin em Chrétien de Troyes e em Wace é incorporado na história da Távola Redonda e do próprio Santo Graal, mas é em Merlin, de Roberto de Boron, que a lenda recebe conotação cristã, tocando, até hoje, os imaginários pelas recepções e apropriações do mito.

Por exemplo, ideias como as de bondade e justiça divina, presentes na obra, estão regulamentadas pela Igreja, já que entre os séculos XII e XIII a maior instituição da Europa Ocidental Medieval criou profundas raízes na sociedade, estabelecendo firmemente o poder eclesiástico (ALMEIDA, 2012, p.36).

Diferentemente das obras posteriores, em que Merlin guia o pai de Artur, Uter, até o nascimento do filho, em Roberto de Boron, Merlin guia não só o pai, mas também o próprio Artur. O fim da narrativa se dá até o mago ficar preso pelos encantamentos de sua aprendiz, Nynianne. De acordo com Bogdanow, Roberto de Boron escreveu a primeira Arturíada coerente (SILVA, 2002, p.41-42; BOGDANOW, 1994, p.180).

A fim de termos uma compreensão mais elaborada de Merlin, buscamos analisar a história que antecede a obra aqui analisada, Joseph ou José de Arimateia. O enredo da história se desenvolveu a partir da traição de Judas. Uma das características importantes e inéditas dos ciclos arturianos que podemos constatar na obra de Roberto é a incorporação de elementos como a Távola Redonda e o Santo Graal.

Segundo o autor, na época de Jesus era comum o "mordomo" receber dez por cento daquilo que seu senhor arrecadava. Maria Madalena havia passado um unguento nos pés de Jesus e Judas estava convencido que aquele unguento valia pelo menos trezentas moedas, então, trinta moedas que equivaleria aos dez por cento, deveria ser dele. Como sabia que não conseguiria o dinheiro das mãos de Maria Madalena, muito menos de Jesus, Judas pensou que, se vendesse Jesus aos perseguidores, conseguiria suas trinta moedas. Após ser vendido e crucificado, um soldado de Pilatos, José de Arimateia, por amar Jesus Cristo, pediu, após a crucificação, como recompensa por seus serviços prestados há anos, o corpo de Jesus. 
Pilatos deu a José o corpo e um vaso que lhe havia sido entregue por um dos judeus que prendeu Jesus. José, ao retirar o corpo de Jesus da cruz, coletou o sangue de suas feridas no vaso e com a ressurreição de Jesus, e o sumiço de seu corpo, José foi acusado e preso. É nesse momento que Jesus vai ao inferno ${ }^{230}$ e, após sua descida, os demônios se reúnem em conselho e decidem engravidar uma mulher na terra, sendo este o motivo do nascimento de Merlin.

Na prisão de José, Jesus aparece para ele em forma de luz e diz que todos vão se lembrar da boa ação de José, em cuidar do corpo de Cristo morto. Ademais, o vaso (Graal) seria o símbolo da trindade, pois o sangue nele contido possuía o poder do Deus Pai, do Filho e do Espírito Santo. Assim, quando José precisasse de conselho sobre o que fazer, ele deveria perguntar ao Graal, e o Espírito Santo daria sempre bons conselhos.

Ainda no livro, uma passagem importante a se destacar é a de que Vespasiano sofria de lepra e estava à beira da morte. Tendo ele ouvido rumores de que na Judeia um profeta fazia muitos milagres, pensou que poderia ser curado. Entretanto, quando descobriu que esse homem havia sido crucificado, ficou bastante irritado, mandou seus soldados para punir os responsáveis por tal ação e, então, Vespasiano envia seus soldados para saber quem foi esse profeta e como ele era caracterizado: “(...) 'Quem foi este profeta de quem tanto se falou?' Eles [judeus] responderam que ele realizou os maiores milagres e maravilhas do mundo; ele era um feiticeiro". ${ }^{231}$

Enchanter, na tradução para o português significa feiticeiro, encantador ou mágico, o que nos aponta que os judeus qualificavam Jesus de acordo com seu poder de operar maravilhas. Essa observação é bastante importante quando estabelecermos relação entre Jesus e Merlin, pois ambos são abençoados por Deus. O primeiro é filho de Deus, o segundo abençoado em favor de sua mãe, mas ambos são reconhecidos por suas atividades mágicas, aconselham pessoas e propiciam os caminhos para que um plano divino se cumpra.

\footnotetext{
${ }^{230}$ While all this was happening, Our Lord descended into Hell, broke in and set free Adam and Eve and as many others as He pleased. And He returned to life, unknown and unseen by those who were standing guard (...)". In: BORON, 2001, p.19.

231 “(...) 'Who was this prophet of whom so much has been spoken?' They [jews] replied that he performed the greatest miracles and wonders in the world; he was an enchanter" BORON, 2001, p.27. Na versão em francês a palavra usada é enchanteur.
} 
Roberto, ao escrever Merlin, enfatizou o caráter cristão do personagem conferindo-lhe uma função mágica e profética vinculada à religião cristã, diferentemente de Godofredo que, em Vita Merlini, colocou os elementos cristãos como componente meramente subentendido, sem participar da trama central. Porém, o Merlin, de Roberto de Boron, assim como o Merlin, de Godofredo, também é filho de um íncubo com uma donzela devota do Deus judaico-cristão. Por ser filho de um demônio, Merlin herdou as memórias e lembranças de toda a história do mundo, e, pela misericórdia divina, Deus se compadeceu de sua mãe e lhe concedeu pela graça a visão de acontecimentos futuros.

Além da origem de Merlin ser a mesma em Godofredo e Roberto, é importante destacar alguns pontos similares entre Merlin e a Historia Regum Britanniae como: (i) o vínculo de ambas as histórias com os dois dragões (um vermelho e outro branco)232, (ii) as mortes diferentes do mesmo indivíduo sendo narradas com um fim moralizante e (iii) os personagens de ambas as obras são exemplos de como os elementos medievais, ao mesmo tempo que circulam e possuem aspectos narrativos comuns, também são adaptados e ressignificados a partir do interesse dos autores.

Outro ponto similar entre a obra de Roberto de Boron e a de Godofredo de Monmouth, é que na primeira, Merlin se refugia ocasionalmente na floresta de Northumberland, a fim de encontrar o escrivão de sua história, Brás; e na última, Merlin também vive na floresta, mas exilado. Logo, vemos que ambos os Merlins veem na floresta o seu refúgio.

Uma diferença de ambas as narrativas é que Merlin, na obra de Roberto, ajuda Pendragão e Uter a vencerem os saxões e expulsá-los de vez das terras bretãs, diferenciando-se, assim, da previsão contrária de Merlin em Godofredo de Monmouth. Provavelmente isso se deve ao fato da relação espacial e história diferente que Godofredo e Roberto tinham em relação aos conflitos entre bretões e saxões.

232 Os dois dragões aparecem desde a trama de Nennius. Tanto em Merlin quanto em Historia Regum Britanniae, a profecia de que haveria dois dragões em baixo do castelo de Vortigern que significaria a decisão da batalha entre saxões e bretões é presente nas duas histórias, visível em Merlin de Robert de Boron, op. cit. p. 80-85. 
Em Merlin, o sábio mago ajuda os bretões não só com suas profecias, mas com a sabedoria e as estratégias de guerra. No trecho a seguir podemos perceber alguns elementos que demonstram o caráter de guia e conselheiro em tempos de guerra de Merlin na obra de Roberto:

[...] se confiardes em mim. Permitireis mesmo que se afastem (os saxões) o mais possível da costa. Eles não saberão que tendes as forças reunidas. $\mathrm{E}$ quanto tiverem avançado pelo interior, enviareis as tropas do lado dos navios deles, para mostra-Ihes que quereis impedi-Ihes a fuga. [...] Um de vós dois irá com as tropas persegui-los até o cansaço, de modo que se sintam obrigados a acampar longe do rio, A água Ihes faltará, e os mais valentes temerão pela vida. Vós os mantereis assim dois dias e, ao terceiro, combatereis. Se agirdes assim, asseguro-vos que vossas tropas vencerão (BORON, 1993, p.114).

No excerto percebemos mais característica similares entre Merlin e um druida, assim como em Merlin de Godofredo. O personagem em questão, sob a pena de Roberto, também é um conselheiro do rei em tempos de guerra, característica que foi associada aos druidas. Entretanto, o que lhe confere a confiança de ser conselheiro real é por ser sábio, visível no diálogo entre Pendragão, irmão de Uter, e Merlin“[...] E agora que sei que sois um homem cheio de experiência e de sabedoria, gostaria que permanecêsseis ao lado de meu irmão" (BORON, 1993, p.115).

Em outras palavras, fruto da relação dialética entre o contexto histórico do autor e de suas leituras de escritos do ciclo artuariano, Roberto apresenta a síntese de um Merlin que, apesar de ser cristão por toda influência do cargo eclesiástico do autor e de estar inserido no contexto das Cruzadas, carrega elementos célticos, provenientes de obras como as de Godofredo.

\section{Considerações Finais}

Em Merlin, diferentemente de Vita Merlini e até de outros escritos do próprio Godofredo, sabemos como o personagem Merlin é representado, em boa parte da narrativa, como um idoso, mas também, em pouquíssimas ocasiões, para causar 
confusão e testar pessoas, se figura de jovem mensageiro. Disto, segue-se que é interessante notarmos que, diferentemente do personagem descrito por Roberto, 0 Merlin de Godofredo e de Chrétien de Troyes são retratados como jovens. Isso pode nos indicar que a associação entre a velhice e o personagem possivelmente surgiu na narrativa de Roberto que por influências de seus estudos clericais ou de algum tipo de tradição narrativa, seja visual ou não, de representar sabedoria vinculada à velhice.

O que podemos perceber é que, apesar de serem histórias diferentes, em Vita Merlini, o autor apresenta Merlin como rei, estabelecendo diálogo direto com o local do personagem (a atual Grã-Bretanha), apresentando críticas políticas à guerra civil vivida por Godofredo, que frequentava a corte da dinastia Normanda e discordava do posicionamento de Estevão I. Vemos, também, um cristianismo timidamente colocado num enredo que transborda elementos célticos (a natureza, a astronomia, os encantamentos, a semelhança de Merlin com um druida). E, por fim, é apresentado uma despreocupação em realçar aspectos profundos do personagem, personagem esse que serviu de canal para uma crítica à sociedade em que Godofredo se inseria.

Já em Merlin, Roberto apresenta o personagem como aquele que continua o serviço de Cristo, ou seja, mesmo Merlin também se assemelhando ao druida, os elementos cristianizadores, morais, bondosos e justos de sua obra são mais explícitos. Também vemos uma dupla ligação espacial de Merlin nessa narrativa: com a Bretanha do século $V$, época em que ambas as obras retratam os acontecimentos, e, também, com o contexto sociopolítico do autor, a França.

No período em que Roberto escreveu se deu o início do processo de centralização de poder nas mãos do rei. Portanto, colocar Artur como o rei cristão capaz de unir todos os povos fragmentados por invasões estrangeiras e guiado por Merlin, um profeta abençoado por Deus, seria como apresentar os dois poderes da França unindose num mesmo propósito, ou seja, fazer a vontade de Deus através do estabelecimento de um monarca forte que, através da guerra santa, protegesse o "patrimônio" cristão e elevasse a bandeira do cristianismo por onde quer que esse passasse.

Se observarmos as descrições visuais do personagem Merlin aqui analisado, em Godofredo de Monmouth, Merlin é um jovem e em Roberto de Boron, Merlin apresenta 
figuração majoritariamente senil. Essa segunda descrição se configura como um aspecto importante que será apropriado por outros autores posteriormente, a fim de conferir mais poder à característica de sábio e experiente que, no imaginário popular, é vinculado a pessoas mais velhas, diferindo-se dos Merlins das narrativas de Godofredo que são apresentados como jovem.

Além disso, ambos os Merlins aparecem e desaparecem muitas vezes durante toda a narrativa, sem dar sinais de quando voltariam e para onde teriam ido. Todas as vezes que o Merlin de Godofredo "some" da vista dos demais personagens, ele se encontra escondido na floresta junto aos animais e plantas. Similarmente, o Merlin de Roberto de Boron, ao desaparecer, vai também à floresta, mas para encontrar seu confessor, Brás, e contar-Ihe suas experiências, a fim de que ele escreva um livro sobre todas as suas aventuras.

No início do texto lançamos o questionamento de como os magos no medievo foram colocados nessas narrativas e defendemos que o personagem Merlin do ciclo arturiano da Idade Média, foi inserido em teatros, novos ciclos arturianos da modernidade e contemporaneidade, bem como em pinturas e representações cinematográficas. Assim, os magos medievais tornaram-se modelos para outros.

Todavia, os elementos vinculados à imagética partem de uma recriação medieval pautada na contemporaneidade e na reafirmação desses autores em construírem obras "típicas" medievais - e, ao escreverem, constroem uma Idade Média distinta da qual elencamos como medieval -, pautados, muitas das vezes, nos novos elementos que são incorporados nesse arquétipo e nessa ideia de Idade Média pelo Romantismo, por exemplo.

Apesar do Merlin de Roberto de Boron ser velho, em nenhum momento, nem na iluminura de uma das cópias, ele aparece com cabelos e barbas longas. Essa reconstrução imagética tem relação com o Renascimento, recuperando uma estética greco-romana para as esculturas e pinturas. Tal representação se massifica no Romantismo, quando as divindades célticas, como Odin, passam a ser pintados com cabelos longos, barbas longas e cajados, transformando essa representação entre o 
pastoril e o divino, um clichê copiado para todos os personagens da mesma origem que tivessem esse ar divinal ligado a natureza.

Os Merlins medievais e outros magos contemporâneos, como Gandalf de J.R.R. Tolkien na literatura, e de Peter Jackson, no cinema, e Dumbledore de J.K. Rowling na literatura e interpretado no cinema por Richard Harris e Michael Gambon, possuem alguns pontos comuns: (i) são personagens dotados de mistério, (ii) aparecem e desaparecerem na narrativa sem uma explicação exata do que foram fazer durante esse período e, uma outra característica comum aos personagens mágicos é que (iii) eles foram colocados nas narrativas como elemento que resgata o passado, seja um passado céltico para a Grã-Bretanha dos séculos XII e XIII ou seja a Idade Média fantasiosa para os séculos XX e XXI.

O entendimento de Idade Média que podemos ter a partir dessas literaturas e adaptações contemporâneas não se trata de conhecimentos apenas do próprio medievo, mas de uma "amálgama de várias Idades Médias [que são] evocadas em um mesmo espaço diegético" (SILVA, 2016, p.20). Ao notarmos que muitos artistas, ao construírem uma narrativa que se passaria nessa "Idade Média", conheciam literaturas típicas do próprio período, conseguimos compreender o diálogo proposto através de uma adaptação e ressignificação de elementos medievais, imbricando seu contexto de produção, outras leituras, seu próprio estilo literário e sua própria vida como inspiração para as construções narrativas.

Como Groebner aponta "esta época [a Idade Média] foi literalmente criada através de desejos, por mais de centenas de anos e, desde então, ela é projetada, esboçada, equipada e mobiliada com os desejos" (GROEBNER, 2008, p.11). Em outras palavras, as obras não lidam somente com as leituras de obras medievais, mas também, e principalmente, com todos os elementos trabalhados, construídos e ressignificados no decorrer dos tempos.

Os próprios escritos medievais também se transformam com o contexto e estilo dos autores. As localidades, os contextos políticos, as emergências sociais e os meios culturais são distintos e tais elementos são importantes para a construção das obras que se configuram enquanto literatura e história. Ademais, a própria construção do mito 
arturiano perpassa questões mais antigas que a própria datação do medievo, por exemplo, quando Godofredo de Monmouth escreve que Merlin transforma Uter no marido de Igerne, a fim de que ao enganá-la, ele possa dormir com ela, pode ter tido sua inspiração na mitologia grega que retrata as diversas transformações de Zeus em homens que estão na guerra, com a finalidade de dormir com suas esposas, enganandoas. Ou seja, a própria produção dos artistas medievais passam por adaptações e ressignificações de outros tempos.

Até mesmos os escritos de Roberto de Boron partem de um conjunto de leituras da lenda arturiana do próprio autor, tendo como base, inclusive, Godofredo de Monmouth, o primeiro a vincular o personagem Merlin ao Artur. E, não obstante, elementos da Alta Idade Média são recuperados por ambos os autores que se encontram, temporalmente, na Idade Média Central e Baixa Idade Média, como exemplo o druidismo e suas características de atuação, função e importância social.

$\mathrm{O}$ arquétipo de mago, se configura, então, pelos elementos medievais que foram construídos por Godofredo de Monmouth e Roberto de Boron. A ligação dos medievais com os magos atuais, centram-se principalmente nas questões que envolvem enredo e, no caso de Roberto de Boron, a velhice na composição imagética do sábio Merlin. Mais abertamente e enfaticamente, as imagens e impressões de um medievalismo construído historicamente, que parte das recriações propostas pelos autores e, também, diretores - e demais envolvidos, como roteiristas e produtores - nas adaptações cinematográficas são o ponto fulcral das construções dos magos atuais.

\section{Referências}

BIRKHAN, Helmut. Some remarks on the druids. Berlin, New York: Walter de Gruyter, 2003.

BORON, Robert. de. Merlin. Trad. Alexandre Micha. Rio de Janeiro: Imago Ed., 1993.

Merlin and the Grail: Joseph of Arimathea, Merlin, Perceval: The Trilogy of Arturian Prose Romances attributed to Robert de Boron (Arturian Studies), NED - New Edition, 2001. 
. Histoire du Saint-Graal, et Histoire de Merlin. Disponível em <http://gallica.bnf.fr/ark:/12148/btv1b52505676x>. Acesso em 15 nov de 2017. DAVIS, Ralph. H. C. King Stephen, Yale English Monarchs Series, 3a. Ed, 1990.

MERKALE, Jean. Merlim, o mago. Trad. Francisco José P. N. Vieira. Rio de Janeiro: Paz e Terra, 1989.

MONMOUTH, Geoffrey. de. Vita Merlini. Disponível em: http://www.sacredtexts.com/neu/eng/vm/vmlat.htm. Acesso em: 15 jan. 2017.

. Vida de Merlin. Trad. Lois C. Pérez Castro, 4ạ. Ed., Madrid: Editora Siruela, 1994.

PEREIRA, Rita. C. M.; MATIAS, Kamilla. D. De mago, profeta e louco... Merlin na historiografia e na literatura dos séculos XII e XIII. Brathair (Online), v. 13, 2013, p. 6382.

SILVA, Danielle. G. G. O mito de Merlin na Idade Média e no Romantismo alemão. Brathair (Online), v. 2, 2002, p. 36-44.

SILVA, Danielle. Sobre "cavaleiras": a (re) criação do medievo em Corneia Funke. Pandaemonium, São Paulo, v.19, n.29, nov-dez, 2016, p.1-20.

ZIERER, Adriana. Da ilha dos bem-aventurados à busca do Santo Graal: uma outra viagem pela Idade Média. São Luís: Editora UEMA, 2013.

ZIERER, Adriana. Artur: de guerreiro a rei cristão nas fontes medievais latinas e célticas. Brathair (Online), v. 2, 2002, p. 45-61.

ZUMTHOR, Paul. A letra e a voz. Trad. Amálio Pinheiro e Jerusa Pires Ferreira. São Paulo: Companhia das Letras, 1993. 